\title{
The Utilization of Microscopy in Developing Investigative Leads from the Examination of Microscopic Trace Evidence in Forensic Investigations
}

\author{
Skip Palenik ${ }^{1}$ and Christopher S. Palenik ${ }^{1}$ \\ ${ }^{1}$ Microtrace LLC, Elgin, IL, USA
}

The majority of trace evidence examinations, performed in laboratories of forensic science throughout the world, are of a comparative nature. Questioned (Q) items of evidence (e.g., fibers, hair, glass, paint, soil) from a crime scene (or victim, suspect, location, etc.) are compared to suspected items of known $(\mathrm{K})$ origin to determine the likelihood that the $\mathrm{K}$ and $\mathrm{Q}$ items could have originated from the same source. The justification normally invoked for performing these comparisons is Locard's Exchange Principle, which states that whenever two objects come into contact there is a transfer of material between them. The original research into the analysis of dust traces, which led Nickolls ${ }^{1}$ in 1956 to recognize and name this principle, was performed by Edmond Locard between 1910 and 1965. Since then, this principle has been repeatedly validated by means of published research and casework. The research reports describe the results of transfer experiments, most often with fibers, performed by forensic scientists from around the world. The results of these experiments have all confirmed Locard's original premise. Published casework reports also confirm the utility and value of microscopic traces in demonstrating contact between individuals, vehicles, sites, etc., to events in question, even when no eye witnesses were present to give testimony.

It is far less common in real life, in spite of what the public expects from reading detective fiction, for the forensic trace evidence examiner to instead analyze microscopic trace evidence for the purpose of developing from it, investigative leads. The reason for this is, of course, that it is a far more difficult undertaking to make evidence answer questions about itself (where did it came from, what process produced it, what was it used for, how did it get there, etc.) and those of the detectives and crime scene investigators who are trying to solve a crime than to perform a comparison between $\mathrm{Q}$ and $\mathrm{K}$ items. It is, however, a far more interesting and intellectually demanding challenge, since in addition to performing intricate analyses of vanishingly small quantities of unknown substances and single small particles to establish certain facts, which the traces can provide about their identity and nature, it also requires the rigorous application of both reason and imagination to interpret the findings. The imagination referred to here is not that of a "wild flight of fancy" or drug induced coma but rather its use, as explained by Poe in the Purloined Letter and the Murders in the Rue Morgue, to develop a range of hypotheses and scenarios to explain the factual results in terms of the questions to be answered. The ability to come up with plausible hypotheses and be able to confirm or reject them based on the existing evidence requires that reasonable hypotheses be formulated in the first place. The ability to formulate these hypotheses requires a well-developed imagination; the ability to rigorously analyze and interpret them requires the application of reason and logic.

The authors' interest has been drawn to these types of problems and they have been fortunate to have been often called upon to apply their intellect and imagination, as well as their skills as microscopists and chemists, to the solution of problems of this type. Three case histories, each highlighting different type of problem, have been chosen to illustrate the practical application of the points discussed here. The first case illustrates the techniques used in tracing the source of soil substituted for commercial goods shipped from Italy to Canada. The second describes the search for body of a young boy 
kidnapped, murdered and hidden by his mother. The third explains how the dust from two T-shirts left at two different crime scenes by a serial rapist in Maryland led to his arrest and conviction.

Case 1. When a sealed shipping container from Italy was opened in Toronto, it was found to contain soil and not the products that had been ordered. The container had been shipped by freighter from Genoa, Italy to Montreal and then off-loaded, transferred to a truck and driven to Toronto. The insurance company suspected that the switch had taken place in Genoa but needed to be certain in order to decide who was responsible for covering the risk. The soil was subjected to petrographic and chemical examinations after separating the components of the soil into fractioning and analyzing them by appropriate methods ${ }^{2}$. The results of these examinations proved to the satisfaction of the parties involved that the soil had come from Canada and could not have originated from Genoa.

Case 2. After 6 year old Timothy Pitzen was abducted by his mother, no one expected that she would be found dead of self-inflicted wounds four days later in a motel without him. In her suicide note she said that Timothy was in a safe place but that no one would ever find him. On the last day Timothy was seen alive on video surveillance tape there was a period of rain in northern Illinois where these events occurred. The mother's van had mud on the undercarriage and running boards and this was investigated to determine its source. In spite of the color and texture it was determined that the dried mud on the running boards and undercarriage came from different sources. From the analyses of the soils it was possible to describe the location where the car had stopped during the rain and constrain that location to several counties. A rare mineral that could not survive long in the surface soil of a temperate region helped constrain the location to less than a 30 mile diameter.

Case 3. A serial rapist in Montgomery County, Maryland was still at large after almost two and a half years of crimes during which he had left his DNA on every victim. The police contacted us to see what we might learn from the white $\mathrm{T}$ shirts that he left behind in two cases. Although the shirts were very clean to the eye, it was possible to vacuum significant quantities of dust from both of them. Microscopical and microchemical examinations of the dust revealed that the shirts were worn by the same person and that he was employed indoors as a drywall installer and finisher. We were also able to infer that he carried out his trade on large scale commercial projects and not just small construction projects. This description, along with other facts established from the composition of the dust, was disseminated to the news media by the police. Shortly thereafter the detective who sent us the clothing called to report that our results led directly to the arrest of the perpetrator and although he later recanted his confession to the arresting officers was faced with explaining the presence of his DNA in all of the victims.

References:

[1] Nickolls, L.C., The Scientific Investigation of Crime, Butterworth \& Co., London, 1956, p.39

[2] Palenik, Skip, Chapter 37. Heavy Minerals in Forensic Science in Mange, M.A. and Wright, D.T., Heavy Minerals in Use, Elsevier, 2007, pp.937-961 